\title{
EGFR Status Assessment for Better Care of Early Stage Non-Small Cell Lung Carcinoma: What Is Changing in the Daily Practice of Pathologists?
}

\author{
Paul Hofman 1,2 (D) \\ check for \\ 1 Laboratory of Clinical and Experimental Pathology, CHU Nice, FHU OncoAge, Pasteur Hospital, \\ Université Côte d'Azur, 06108 Nice, France; hofman.p@chu-nice.fr; Tel.: +33-492-038-855; Fax: +33-492-8850 \\ 2 CHU Nice, FHU OncoAge, Hospital-Integrated Biobank BB-0033-00025, Université Côte d'Azur, \\ 06000 Nice, France \\ Abstract: The recent emergence of novel neoadjuvant and/or adjuvant therapies for early stage \\ (I-IIIA) non-small cell lung carcinoma (NSCLC), mainly tyrosine kinase inhibitors (TKIs) targeting \\ EGFR mutations and immunotherapy or chemo-immunotherapy, has suddenly required the evalua- \\ tion of biomarkers predictive of the efficacy of different treatments in these patients. Currently, the \\ choice of one or another of these treatments mainly depends on the results of immunohistochemistry \\ for PD-L1 and of the status of EGFR and ALK. This new development has led to the setup of different \\ analyses for clinical and molecular pathology laboratories, which have had to rapidly integrate a \\ number of new challenges into daily practice and to establish new organization for decision making. \\ This review outlines the impact of the management of biological samples in laboratories and discusses \\ perspectives for pathologists within the framework of EGFR TKIs in early stage NSCLC.
} updates

Citation: Hofman, P. EGFR Status Assessment for Better Care of Early Stage Non-Small Cell Lung Carcinoma: What Is Changing in the Daily Practice of Pathologists? Cells 2021, 10, 2157. https://doi.org/ $10.3390 /$ cells10082157

Academic Editor: Lucas Treps

Received: 6 August 2021

Accepted: 19 August 2021

Published: 21 August 2021

Publisher's Note: MDPI stays neutral with regard to jurisdictional claims in published maps and institutional affiliations.

Copyright: (C) 2021 by the author. Licensee MDPI, Basel, Switzerland. This article is an open access article distributed under the terms and conditions of the Creative Commons Attribution (CC BY) license (https:// creativecommons.org/licenses/by/ $4.0 /)$.
Keywords: non-small cell lung carcinoma; early stage; targeted therapies; EGFR; molecular tests

\section{Introduction}

Developments in the treatment of patients with advanced stage non-small cell lung carcinoma (NSCLC) have improved not only the overall quality of life but also the life expectancy of these patients [1,2]. For a long time, treatment of early stage NSCLC included only surgical resection, sometimes associated with radio-chemotherapy or neoadjuvant or adjuvant chemotherapy [3-5]. In fact, these associated treatments provided a moderate benefit in terms of progression-free survival and overall survival $[3,4]$. The recent results of adjuvant therapy targeting activating mutations in EGFR (exon 19 deletion and L858R mutation) and of preoperative immunotherapies of early stage (I-IIIA) NSCLC open up great perspectives for the prevention of relapse and/or post-operative tumor progression [6-14]. In this context, laboratories of pathology have been required to meet new challenges in developing a number of analyses to assure optimal care of patients in a routine clinical practice. Therefore, it is mandatory to look for different biomarkers, including PD-L1 assessment by immunohistochemistry (IHC), and EGFR status evaluation by molecular testing $[15,16]$. Currently, PD-L1 IHC in tissue samples is the only biomarker used routinely as a companion diagnostic test for the assessment of predictive immunotherapy and immunochemotherapy efficacy in thoracic oncology [15-17]. Thus, PD-L1 IHC was used as a predictive biomarker in clinical trial development for early stage NSCLC treated with immune checkpoint inhibitors (ICIs) [11-13]. After briefly presenting the main current clinical trials concerning the anti-EGFR targeted therapies in early stage NSCLC, this review will deal with the different steps for the setup and management of predictive tests that must be performed in laboratories for the care of these patients. Then, it will address the associated issues and constraints concerning this new opportunity. 


\section{Short Overview of Studies concerning the Use of EGFR TKIs in Early Stage NSCLC in Neoadjuvant and Adjuvant Setting}

Different clinical trials have been performed with the aim to evaluate the efficacy of TKIs targeting activating mutations in EGFR in the neoadjuvant and also in the adjuvant setting [18-20]. Briefly, these trials have used or use inhibitors of the first, second, and third TKI generation $[19,21]$. Some of these trials have given relatively disappointing results, in particular for the first and second generation of TKIs, which have not provided a significant benefit to patients in terms of quality of life and absence of recurrence and overall survival [22]. However, recent studies, in particular the ADAURA study which used osimertinib, a third generation TKI, as an adjuvant for non-epidermoid NSCLC (stage IB-IIIA completely surgically resected) with an exon 19 deletion or an L858R mutation in EGFR, were positive compared to a placebo for progression-free survival [14]. Studies using other third generation TKIs (such as afatinib (NCT01746251 trial) or almonertib (NCT0468741 trial)) as an adjuvant after complete surgical resection are also ongoing. Clinical trials with other third generation TKIs targeting EGFR mutations in a neoadjuvant setting (such as the NEOADAURA study (comparison of treatment with osimertinib versus osimertinib and chemotherapy versus placebo and chemotherapy) or the afatinib trial (NCT04470076 trial)) have also been developed for early operable stages of NSCLC [23].

In this context, the positive results of the ADAURA study have recently led the Food and Drug Administration (FDA) and, subsequently, the European Medicines Agency (EMA) to approve the use of osimertinib for early stage NSCLC with the activating mutations defined above $[24,25]$. Thus, the systematic search for EGFR mutations in early stage non-squamous NSCLC has become obligatory in any pathology laboratory. Therefore, it is crucial to highlight that the current approval of osimertinib is restricted to the adjuvant therapy after complete tumor resection in adult patients with stage IB-IIIA non-squamous cell lung carcinoma harboring EGFR exon 19 deletions or exon 21 (L858R) substitution mutations [24,25]. Until now, these stages of I-IIIA lung cancer patients having other subtypes of genomic alterations, such as EGFR exon 18, non L858R exon 21 or T790M, and non T790M exon 20 mutations, could not be treated with osimertinib [24,25]. Moreover, it is noteworthy that the possibility of proposing, at an early time, targeted therapies oriented not only to these latter EGFR mutations but also to other genomic alterations in these early stages is presently being investigated, and it may also be soon that some of them are administrated in daily practice in the near future [26].

\section{Which Biological Sample for Evaluation of the EGFR Status of Early Stage NSCLC?}

The EGFR status of tumors of patients with advanced stage NSCLC can be evaluated with several biological sources: (i) tissue biopsies (of bronchial or transthoracic origin); (ii) cytological samples (from transbronchial or transthoracic fine needle aspiration; fluid effusions, in particular pleural or cerebrospinal; and bronchoalveolar lavage); (iii) blood samples, mostly from circulating free DNA and sometimes from circulating tumor cells (CTCs); and, more rarely, (iv) surgical specimens [27] (Figure 1). All of these samples can also be analyzed in early stage NSCLC for genomic alteration assessment, though, at the moment, the majority probably consist of surgical specimens and, less frequently, biopsies. Thus, a number of questions can be asked. Notably, for adjuvant TKI, is it preferable to evaluate the preoperative status of EGFR on tissue biopsies, or is it better to look for the EGFR mutations on surgical specimens? In fact, preoperative assessment is certainly the ideal situation, knowing that it is necessary to obtain the EGFR and $A L K$ status before envisaging neoadjuvant immunotherapy or neoadjuvant immunotherapy and chemotherapy [28]. Thus, the preoperative choice of therapy (with neoadjuvant and/or adjuvant administration of targeted molecules) must be made before surgery [28]. However, a number of limits may exist [29-31]. The size of the biopsy samples is more and more often small, in part due to the optimization of endoscopic techniques with the use of supple small caliber endoscopes that give access to distal tumors [32]. In this setting, molecular biological tests can give false negative results. This may be due to the extraction of an insufficient number 
of nucleic acids for sequencing analyses (notably due to a low percentage of tumor cells, below $20 \%$ among most recommendations, or to an extensive area of necrosis) and/or to a poor quality of these extracted nucleic acids (due to hyper- or hypo-fixation of the tissue or, very exceptionally, to a long period of cold ischemia time with a delay in fixation). Although controversial, false negative results for EGFR mutations can also result from tumor heterogeneity [33-36]. When this is the case and in the absence of an identifiable mutation, it is certainly necessary to systematically evaluate the EGFR status of the resected specimen. Though rare, mutations in EGFR can also be investigated with preoperative cytological samples, but negative results require secondary analysis of the mutational status of the surgical specimen $[37,38]$. The practice of liquid biopsies (LB) has strongly modified the care of advanced stage NSCLC patients, not only during progression but also, recently, at diagnosis [39-43]. Thus, LB can correspond to different fluids including blood samples but also pleural, pericardial, and ascites effusions or cerebrospinal fluid [44-46]. In particular, these different LBs can be used in advanced stage NSCLC patients to detect genomic alterations that are accessible to targeted therapies [39-46]. However, the sensitivity of blood samples for EGFR evaluation is globally low for solid tumors at an early stage of NSCLC, given the low number of free nucleic acids circulating in the blood and/or of the low number of CTC detections associated with an EGFR mutation [47,48]. Thus, preoperative evaluation of the EGFR status with blood samples is associated with a high percentage of negative results. Testing EGFR status from other LBs (notably from pleural effusions) is not useful since, by definition, pleural involvement is absent in early stages of NSCLC. When a very low amount of circulating tumor DNA is present in the plasma sample, certain technical approaches, but also better control of pre-analytical blood handling processes, could optimize detection of genomic alterations [49-51]. LB performed at different post-operative times can quantify the circulating tumor DNA and/or identify the presence of mutations in EGFR, which can point to recurrence or tumor progression [52]. Additionally, apart from CTCs and circulating tumor DNA, blood samples from lung cancer patients can contain other circulating components of strong interest, such as extracellular vesicles (EVs) [53-56]. Therefore, all cells, including tumor cells, can release EVs in the blood stream, which are broadly divided into ectosomes and exosomes. More and more studies have focused on exosomes' assessment in LB because of their potential not only in lung cancer diagnosis and prognosis but also as predictive biomarkers for different treatment in NSCLC patients [53-56]. The evaluation of the EGFR status with surgical specimens must meet a number of requirements. The specimen of tissue for nucleic acid extraction must be selected with caution and needs to correspond to a fragment rich in tumor cells while avoiding areas of strong inflammation and/or extensive sites of necrotic foci. It is often necessary to enrich the number of tumor cells by macro-dissection before the extraction of nucleic acids, notably to limit the amount of germinal DNA associated with the tumor DNA. In addition, the pre-analytical phase must be well-managed to avoid a long period of cold ischemia, which leads the nucleic acids to degrade. It is recommended that the time between surgical resection and fixation with formalin be no more than one hour $[29,57]$. The fixation time of the surgical specimen must be also controlled and must usually be between eight and eighteen hours depending on the size of the resected specimen [29]. It is evident that the organization of the laboratories, the surgical programs, the length of the operations, and the agendas corresponding to the surgery, in particular before a weekend or public holiday, can have a strong impact on variations to the different pre-analytical parameters. More rarely, false positive results with artifactual mutations in EGFR resulting from deamination due to formalin over fixation can also occur [30]. This emphasizes the importance of mastering the different pre-analytical parameters [58]. When there is a tumor heterogeneity, it is probably not necessary to look for mutations with several tissue blocks of the same resected tumor since the tumor surface for analysis is in general sufficiently large on a selected block. Nonetheless, to our knowledge, no study has verified the presence of mutations in EGFR on a sufficient number of tissue samples 
obtained from a surgical specimen to ensure the presence or absence of such a molecular heterogeneity.

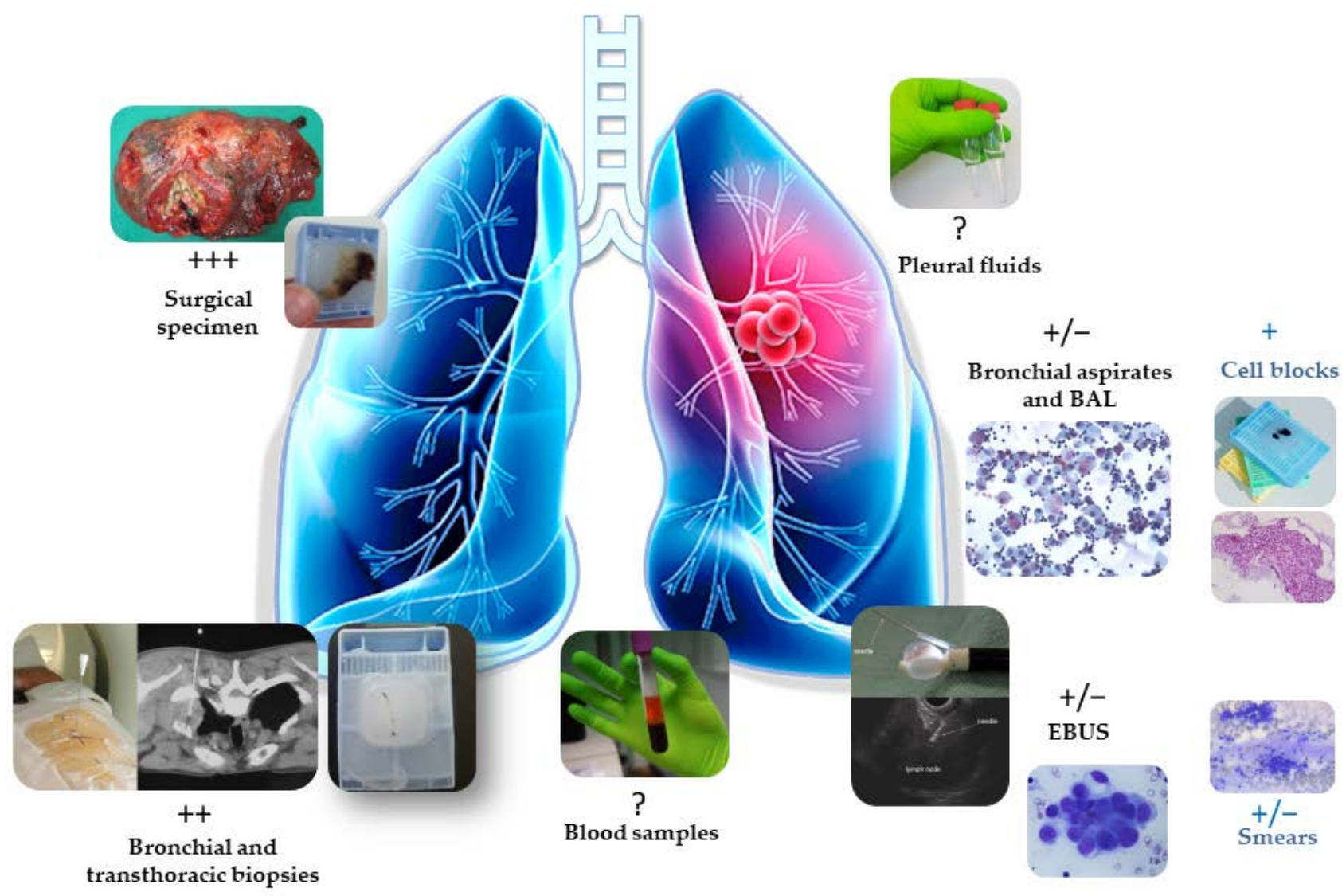

Figure 1. Different sources of biological specimen available for EGFR status assessment in early stage NSCLC. BAL, bronchoalveolar lavage; EBUS, endobronchial ultrasound biopsy. According to the samples, the assessment of genomic alteration can be globally more or less easy since the quantity of extracted nucleic acids is generally variable in these samples (+++: very high quantity; ++: high quantity; +: moderate quantity; +/-: low quantity; ?: uncertain quantity).

The detection of mutations in EGFR must ideally be done in a reflex way on biopsies (or even on cytological samples) and/or on surgical specimens of all non-squamous NSCLC histological types. The majority of neoadjuvant and/or adjuvant targeted therapies are reserved for EGFR-mutated non-squamous carcinomas, but it is probable that these treatments will be administered in the near future for some exceptional epidermoid NSCLCs mutated on this gene [59]. Thus, this will require evaluation of mutations in EGFR regardless of the histological type of NSCLC [59]. Systematic analysis of the EGFR status on biopsies holds a number of advantages: it (i) diminishes the delay of obtaining molecular results (this is of more specific importance if neoadjuvant treatment with a targeted therapy is envisaged), (ii) avoids treatment with immunotherapy that is poorly effective and even toxic in the case of activating mutations in EGFR, and (iii) associates information with the molecular status of other genes of strong interest (in particular, ALK, ROS1, NTRK, $B R A F, M E T, R E T, N R G 1, H E R 2)$, which helps envisage the initiation of a potential targeted therapy, in particular in the case of recurrence or tumor progression after surgery [60-65]. 


\section{Which Approach(es) for Sequencing Technology?}

The evaluation of mutations in EGFR can be performed by targeted sequencing or by "next generation sequencing" (NGS) (Figure 2A,B). The use of an NGS type of approach by most of the clinical trials (for example the ADAURA trial) that target only the L858R mutation and the exon 19 deletion in EGFR thus seems unnecessary since this evaluation can be done by presently commercialized RT-PCR tests, notably those developed within laboratories $[66,67]$. Rapid tests such as those proposed by Biocartis (Mechelen, Belgium) with the Idylla approach or by Roche Diagnostics (Basel, Switzerland) using the COBAS approach can be adapted, too [66-68]. These latter tests can detect a large number of mutations in EGFR, beyond the L858R mutation and the exon 19 deletion [62,67]. In this regard, certain rare mutations in EGFR can be sensitive to TKIs, in particular osimertinib, and may be targeted in the future with adjuvant or neoadjuvant treatment [69]. In addition, certain rare mutations in EGFR may be sensitive to immuno-oncology treatment and therefore should be identified routinely [64]. Moreover, EGFR mutant tumors have differing responses to ICIs and underlying molecular profiles [70]. Nonetheless, interest in performing an NGS test can be strongly debated. In fact, several co-mutations associated with mutations in EGFR have been shown to bring about a lower efficacy to EGFR TKIs, to give tumor resistance to these molecules, and to result in a poorer prognosis [34,71-75]. This notably concerns mutations in TP53, RB, CTNNB1, RBM10, FAT1, ABCB1, PI3KA, and $A R I D 1 A[72,76-80]$. Thus, in the future, the therapeutic strategy may differ according to these mutational associations, which make the prospective collection of this information highly indispensable. Importantly, NGS opens up future avenues to other adjuvant targeted therapeutics in the case of the detection of genomic alterations in other genes (such as ALK, ROS1, BRAFV600, NTRK, RET, MET) that are sensitive to different molecules. Thus, for example, clinical trials are ongoing for patients with operated early stage NSCLC with an $A L K$ rearrangement [81]. When the status of genomic alterations is known at diagnosis, it is possible to consider this information at recurrence or tumor progression, which reduces the delay to administration of a therapeutic, in particular if it is not possible to perform an additional re-biopsy on a patient at that time. These analyses by NGS can be done on preoperative biopsies and/or surgical specimens. As for EGFR, the status of $A L K$ must be evaluated before treatment with neoadjuvant immunotherapy and can also be evaluated by NGS, ideally by RNA sequencing [82]. It is of importance to highlight that NGS with tissue biopsies requires a sufficiently good quantity and quality of nucleic acids to obtain specific and sensitive results. In practice, it can only be used for biopsies with at least more than $20 \%$ of tumor cells (and according to the size of the tissue biopsy), which in general occurs in two out of three cases in daily practice in most situations. 


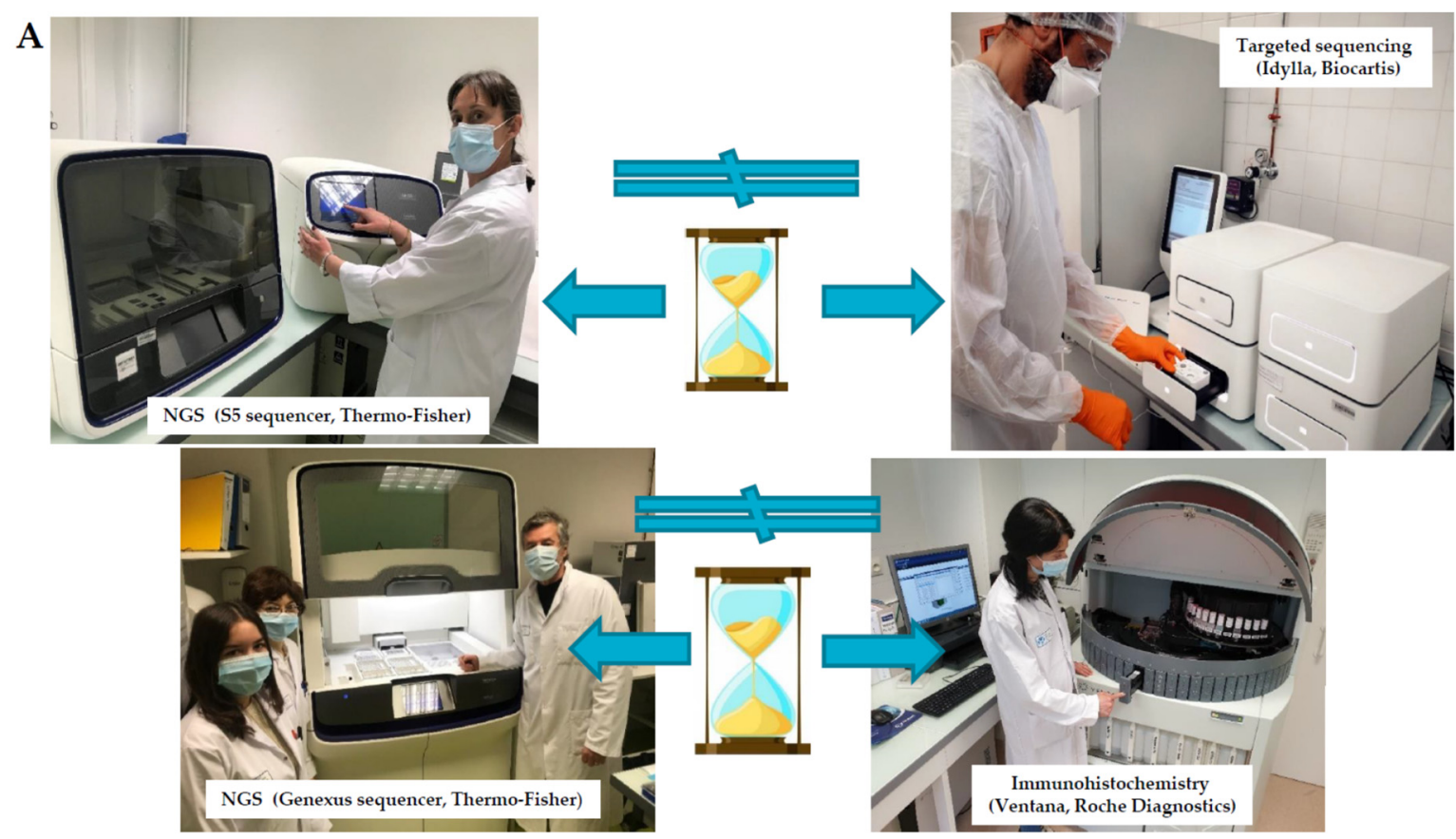

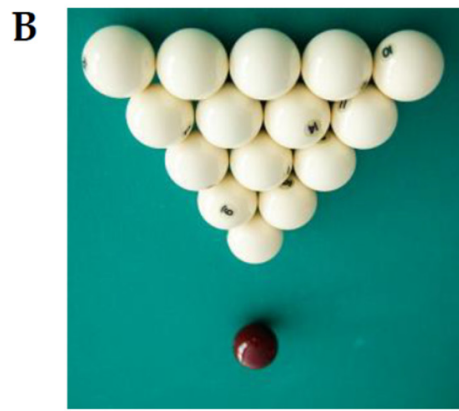

Targeted sequencing (Explores one gene at the same time)

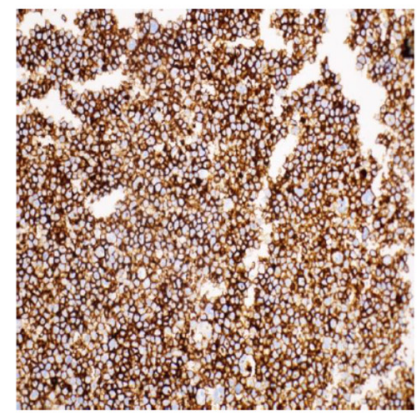

PD-L1 Immunohistochemistry

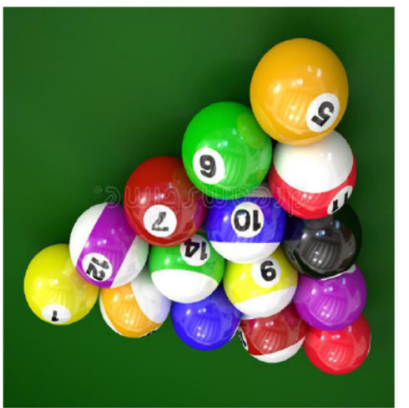

Next Generation Sequencing (Explores many genes at the same time)

Two main challenges:

Getting a short turnaround time in obtaining all the immunohistochemistry and molecular biology results Having samples with enough tumor cells and good quantity \& quality of extracted nucleic acids (both DNA and RNA)

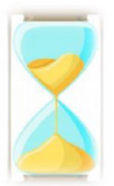

Figure 2. Different approaches to developing in a pathology laboratory for the assessment of predictive biomarkers in the era of neoadjuvant and/or adjuvant therapies for early stage non-small cell lung carcinoma. (A) Examples of different methods setup in a biopathology platform (Laboratory of Clinical and Experimental Pathology, Université Côte d'Azur, Nice, France). (B) Challenges associated with these different methods.

\section{Issues concerning the Cost and Reimbursement}

Reliance on the sequencing strategy as a reflex test has a strong impact on the associated cost of molecular biological tests and can be discussed according to the mode of reimbursement of these tests by institutions, local organizations, and/or countries [83-85]. Thus, a strategy of reflex testing by NGS can be influenced by the capacity to finance these tests $[67,68,86]$. As an example, in France, the invoice associated with these tests is sent to the physicians (oncologists in the majority of cases) who ask for the molecular biology 
prescription [83]. As a matter of fact, the NGS tests are partially reimbursed in France, which incites many oncologists, notably those working in private health care systems, to prescribe RT-PCR tests for the detection of genomic alterations only associated with therapeutic molecules that have received EMA authorization and which are reimbursed [83]. Thus, some medical oncologists will most certainly prescribe only evaluation of genomic alterations in EGFR with respect to the administration of neoadjuvant and adjuvant therapeutics targeting activating mutations present on this gene. In fact, some studies show that the cost of NGS does not necessarily exceed the overall cost of several sequencing analyses, if analyses are not limited to the evaluation of the status of the three genes (EGFR, $A L K$, and ROS1) [87,88]. Thus, in the future, an increase in the number of therapeutic targets and genes to be examined, for care of early stage NSCLC patients, will rapidly result in a higher cost for sequential analyses compared to that of NGS, in particular with small panels of at least tens of genes $[87,88]$. It is obvious that the systematic setup of the reflex tests will have an impact on the workload of clinical and molecular pathology laboratories. This additional work must be considered within the network of the management of laboratories and hospitals [61]. Finally, it is well-known that the frequency of the different EGFR mutations in NSCLC varies according to countries and continents [89]. In this context, it is also important to consider the cost of the different testing with regard to the cost effectiveness of adjuvant targeted therapy, which has been described in some series comparatively to that of adjuvant chemotherapy [90].

\section{Neoadjuvant Immunotherapy or Neoadjuvant Immuno/Chemotherapy versus Adjuvant Targeted Therapy against EGFR: How to Make the Right Choice?}

Immuno-oncology clinical trials with neoadjuvant therapy (for example, the AEGEAN study, which evaluates the effect of the association of durvalumab and chemotherapy versus chemotherapy alone for resectable stage (IIA-IIIB) NSCLC, or the NEOCAST study, which evaluates the effect of durvalumab alone) or adjuvant therapy (for example, the BR.31, which evaluates the effect of durvalumab, or MERMAID-1, which evaluates the association of durvalumab and chemotherapy versus chemotherapy alone) are currently ongoing for early stage NSCLC in the absence of genomic alterations in EGFR and ALK [13,65,91]. These clinical trials need an examination of PD-L1 tumor cell expression by immunohistochemistry. These predictive biomarkers are evaluated with preoperative tissue biopsies. As an example, the AEGEAN study classifies patients according to stage II or III and to the expression of PD-L1 on tumor cells at a level below or above 1\%. The biomarkers can exceptionally be evaluated on cytological material in the absence of associated tissue biopsies. The number of tumor cells in cytological samples generally allows evaluation of the expression of PD-L1; however, this assessment has to be done in more than one hundred tumor cells, which is not possible in all cases [92-94].

The results of biomarkers must be obtained within a delay that permits neoadjuvant treatments to be initiated, irrespective of the biological material. Thus, it is mandatory to avoid long delays in transmission of the results of PD-L1 immunohistochemistry and of the molecular biology, in particular for NGS analyses [95] (Figure 2A,B). Aside from genetic alteration in EGFR and $A L K$, NGS can identify other genomic alterations (in $B R A F$, RET, MET, ROS1, NTRK, HER2,), some of which can be harmful when neoadjuvant immunotherapy is used [96]. Given the possible intra-tumoral heterogeneity concerning the expression of PD-L1 and mutations in EGFR as well as some false negative results obtained with preoperative biological material, it is certainly interesting to repeat examinations for these biomarkers with surgical specimens in the case of a negative result in preoperative biopsies $[97,98]$.

Finally, it is pivotal for these new therapeutic strategies to use robust tests for predictive biomarker (PD-L1 and EGFR) assessment. Thus, it has been previously demonstrated that patients with EGFR-mutant NSCLC showed a poor or non-response response to immunotherapy $[99,100]$. The mechanisms mediating this resistance of EGFR-mutated NSCLC patients to immunotherapy are not totally elucidated today. However, previous works revealed that EGFR-mutated NSCLCs have lower PD-L1 expression and a low 
tumor mutational burden, leading to weak immunogenicity and, thus, a weak response to ICIs $[99,101]$. In this context, it is crucial to set up molecular biology testing for EGFR evaluation, having both high specificity and sensitivity.

\section{Perspectives and Issues}

The FDA and EMA recently approved adjuvant treatment with osimertinib for early stage non-squamous NSCLC [24,25]. Thus, it is necessary to look for activating mutations in EGFR (L858R and deletion in exon 19) for treatment of IB-IIIA stage non-squamous lung cancer [102]. However, these investigations can certainly be applied to all operable stages including the IA stage and to all histological types of NSCLC including squamous carcinoma with the L858R mutation or the exon 19 deletion. Thus, it maybe rapidly mandatory in the near future to look for these genomic alterations in all stages and histological types of NSCLC. Rare mutations in EGFR can be treated with targeted therapy in adjuvant $[103,104]$. In contrast to certain NSCLCs, rare mutations in EGFR may be not sensitive to TKIs targeting these mutations, and patients may benefit better from immunotherapy associated with or without chemotherapy [70]. Moreover, the development of several third generation TKIs targeting the EGFR mutations opens doors to many clinical trials and new possibilities in the near future for neoadjuvant and/or adjuvant targeted therapies in early stage NSCLC [105]. Follow-up of post-operative patients with an LB can be envisaged to monitor a combination of the quantification of the circulating tumor free DNA and examination for mutations in EGFR as well as other associated genomic alterations [106,107]. If NGS is performed to detect mutations in EGFR, it is important to provide information concerning the genomic alterations present on the different genes associated with mutations in EGFR [34,75]. The mid- and long-term efficacy of osimertinib as a function of the different genetic signatures may in fact be different. Additionally, the ethnic origin of the patients must be taken into consideration, since it is well known that Asians present with a large percentage of early stage mutated NSCLC [108]. A recent study on Chinese patients reported a higher number of EGFR mutations in early stages compared to advanced stages [109]. The latter result was not observed in another study performed in patients living in the USA [75].

The sudden onset of the recent COVID-19 pandemic and the different successive waves associated with the worldwide severe acute respiratory syndrome-associated coronavirus 2 (SARS-CoV-2) infection led to a strong impact on the surgery of patients having early stage NSCLC, with a global decrease of thoracic surgical activity, an increase of delay for lung cancer resection, and certainly an increase of lung cancer mortality [110-112]. In the same period, a strong decrease of molecular biological activity in NSCLC patients for genomic alteration detection, including the assessment of EGFR mutation, was observed in most of the countries and institutions [111,113]. In this context, the number of clinical trials, notably those associated with neoadjuvant and/or adjuvant targeted therapy in early stage NSCLC, dropped, and this situation may slow down the development of these patients receiving care with different EGFR TKIs in the near future.

\section{Conclusions}

Pre-operative and/or post-operative treatments of NSCLC by targeted therapies or by immunotherapy (in association or not with chemotherapy) have recently revolutionized the care of early stage lung cancers and thus may prevent recurrence and progression of these tumors after surgery. Apart from the targeted therapy which has been described above, early stage NSCLC wild type for EGFR and ALK can benefit from neoadjuvant and/or adjuvant immunotherapy or immunochemotherapy in the context of ongoing large phase 3 clinical trials $[3,6,12,13,17]$. Therefore, these treatments provide great hope for a cure for all these cancers. However, many challenges are associated with this therapeutic revolution, not only for oncologists but also for pathologists. Thus, with the aim of providing optimal care for patients, laboratories now reflect on many pivotal questions (Table 1). Good practices and analyses of biological specimens (tissue biopsies, cytological samples, blood 
samples obtained before and/or after surgery, surgical specimens) strongly determine the choice of an appropriate therapy based on the evaluation of several predictive biomarkers.

Table 1. Open current and future questions concerning the evaluation of EGFR status of early stage NSCLC patients in the context of neoadjuvant and/or adjuvant therapies using EGFR TKIs.

\begin{tabular}{|c|}
\hline Should we only look for the EGFR status on pre-operative biopsies (bronchial and transthoracic biopsies)? \\
\hline Should we only look for the EGFR status on surgically resected specimens? \\
\hline Should we look for the EGFR status systematically on both biopsies and surgically resected specimens? \\
\hline Is it acceptable to look for the EGFR status on cytological samples only? \\
\hline What is the added value of integrating a liquid biopsy before and/or after surgery for early stage NSCLC patients? \\
\hline Does the assessment of EGFR have to be done only by targeted (RT-PCR) or next generation sequencing technologies? \\
\hline What about the systematic evaluation of the other predictive biomarkers on biopsies (PD-L1, $A L K$, and other genes)? \\
\hline $\begin{array}{l}\text { How can we master the turnaround time in obtaining results, notably in the context of neoadjuvant immunotherapy versus } \\
\text { adjuvant EGFR TKIs administration? }\end{array}$ \\
\hline $\begin{array}{l}\text { How should we consider the landscape of concomitant mutation (notably in TP53, RB, RBM10, CTNNB1, FAT1, ABCB1, ARID1A) in } \\
\text { EGFR } 19 \text { del19/L858R mutated tumors and their association with response to EGFR-TKIs in early stage NSCLC patients? }\end{array}$ \\
\hline How should we consider EGFR mutations out of EGFR 19 del19/L858R? \\
\hline How should we take care of patients with early stage squamous cell lung carcinoma with an EGFR mutation? \\
\hline How should we reimburse the molecular biology reflex tests and receive coverage for the full cost? \\
\hline How should we integrate the induced workload and new infrastructural challenges in the pathology laboratories? \\
\hline How should we anticipate the issues associated with the development of the In Vitro Diagnostic Regulation in Europe? \\
\hline $\begin{array}{l}\text { It is crucial that the laboratory tests be robust (in terms of specificity and sensitivity) } \\
\text { and the management of the biological samples be optimal, knowing that the preoperative } \\
\text { tissue samples are becoming smaller and smaller in size, which requires great collaboration } \\
\text { between oncologists, pathologists, and molecular biologists [29]. Moreover, for a long time, } \\
\text { oncologists have shown interest in LB, given the number of advantages in terms of practice } \\
\text { and facility of execution. However, while the use of these tests is more and more frequent } \\
\text { in patients with advanced stage NSCLC, their use in patients with early stage NSCLC is } \\
\text { still strongly debatable and open to several challenges (Table 2) [40,42]. }\end{array}$ \\
\hline
\end{tabular}

Table 2. Main challenges facing liquid biopsies for early stage NSCLC patients.

\begin{tabular}{c} 
Should we assess the ct-DNA level before and/or after surgery? \\
What is the best timing for blood sampling after complete surgery? \\
How should we define a cutoff for the ct-DNA level after complete surgery? \\
How should we set up a liquid biopsy in new daily practice? \\
\hline How should we determine false and true negative results for EGFR mutation in a liquid biopsy? \\
How should we determine false positive results for EGFR mutation in a liquid biopsy? \\
What are the best practices for mastering the different pre-analytical phases? \\
How should we distinguish cf-DNA and ct-DNA in routine clinical practice? \\
\hline How should we set up blood methods for standardization and validation of molecular biology testing? \\
How should we obtain a mandatory accreditation (such as the ISO 15,189 accreditation in Europe)? \\
How should we reimburse the liquid biopsy in the health care system?
\end{tabular}

The important nature of these novel strategies in thoracic oncology requires laboratories to ensure that the different tests are of the highest quality. Therefore, different external quality controls and accreditations according to international norms must be 
pursued [114]. In addition, the management of the biological tests must respect the current 2022 new legislative regulations for use (which will be applicable from May 2022), while taking into consideration the guidelines concerning the EU In Vitro Diagnostic Regulation (IVDR) [115-117]. By consequence, all manufacturers of in vitro diagnostic tests will be required to obtain certification to distribute the products to their clients. This will certainly offer greater standardization of molecular biology testing. However, this puts strong constraints on the working of many pathology laboratories, given the associated budgetary consequences for the setup and/or maintenance of IVDR for doing targeted sequencing and/or NGS [115-117].

Other different approaches that predict the response or resistance to targeted therapies and immunotherapies will certainly emerge rapidly in the future and must subsequently be integrated into the care of patients with early stage NSCLC [118-122]. Thus, it is certain that aside from EGFR and $A L K$, many other genomic alterations on other genes of interest will systematically be evaluated before immunotherapy or immunotherapy and chemotherapy to justify the therapeutic decision, while considering the benefit/risk of treatment [52]. The complexity of the biological tests will become associated with patient phenotype, genetic and epigenetic analyses, and an extension of therapeutic strategies. It is without any doubt that approaches based on algorithms that integrate developments in artificial intelligence will rapidly be envisaged in the domain of care of early stage NSCLC patients [123].

Funding: This research received no external funding.

Institutional Review Board Statement: Not applicable.

Informed Consent Statement: Not applicable.

Data Availability Statement: Not applicable.

Acknowledgments: The author wishes to thank the "Conseil Départemental des Alpes Maritimes", the "Ligue Départmentale 06 de Lutte contre le Cancer", and the "Cancéropôle PACA".

Conflicts of Interest: The author is a consultant and/or participates in scientific committees for laboratories including BMS, AstraZeneca, Roche, Amgen, MSD, Novartis, Bayer, Eli Lilly, Pierre Fabre, Pfizer, Thermo-Fisher Scientist, Biocartis, and Illumina.

\section{References}

1. Herbst, R.S.; Morgensztern, D.; Boshoff, C. The biology and management of non-small cell lung cancer. Nature 2018, 553, 446-454. [CrossRef]

2. Howlader, N.; Forjaz, G.; Mooradian, M.J.; Meza, R.; Kong, C.Y.; Cronin, K.A.; Mariotto, A.B.; Lowy, D.R.; Feuer, E.J. The Effect of Advances in Lung-Cancer Treatment on Population Mortality. N. Engl. J. Med. 2020, 383, 640-649. [CrossRef]

3. Chaft, J.E.; Rimner, A.; Weder, W.; Azzoli, C.G.; Kris, M.G.; Cascone, T. Evolution of systemic therapy for stages I-III non-metastatic non-small-cell lung cancer. Nat. Rev. Clin. Oncol. 2021, 18, 547-557. [CrossRef]

4. Howington, J.A.; Blum, M.G.; Chang, A.C.; Balekian, A.A.; Murthy, S.C. Treatment of stage I and II non-small cell lung cancer: Diagnosis and management of lung cancer, 3rd ed: American College of Chest Physicians evidence-based clinical practice guidelines. Chest 2013, 143 (Suppl. S5), e278S-e313S. [CrossRef]

5. Spaans, J.N.; Goss, G.D. Epidermal growth factor receptor tyrosine kinase inhibitors in early-stage nonsmall cell lung cancer. Curr. Opin. Oncol. 2015, 27, 102-107. [CrossRef] [PubMed]

6. Ahern, E.; Solomon, B.J.; Hui, R.; Pavlakis, N.; O’Byrne, K.; Hughes, B.G.M. Neoadjuvant immunotherapy for non-small cell lung cancer: Right drugs, right patient, right time? J. Immunother. Cancer 2021, 9, e002248. [CrossRef] [PubMed]

7. Attili, I.; Passaro, A.; Spaggiari, L.; Spitaleri, G.; de Marinis, F. Adjuvant EGFR TKIs in NSCLC harboring EGFR mutations: Looking for a consensus way. Ann. Transl. Med. 2020, 8, 1111. [CrossRef]

8. Broderick, S.R. Adjuvant and Neoadjuvant Immunotherapy in Non-Small Cell Lung Cancer. Thorac. Surg. Clin. 2020, 30, 215-220. [CrossRef] [PubMed]

9. Kang, J.; Zhang, C.; Zhong, W.Z. Neoadjuvant immunotherapy for non-small cell lung cancer: State of the art. Cancer Commun. 2021, 41, 287-302. [CrossRef]

10. Krishnamoorthy, M.; Lenehan, J.G.; Maleki Vareki, S. Neoadjuvant Immunotherapy for High-Risk, Resectable Malignancies: Scientific Rationale and Clinical Challenges. J. Natl. Cancer Inst. 2021, 113, 823-832. [CrossRef] [PubMed]

11. Pall, G. Neoadjuvant immunotherapy in nonsmall cell lung cancer. Curr. Opin. Oncol. 2021, 33, 59-63. [CrossRef] [PubMed]

12. Shukla, N.; Hanna, N. Neoadjuvant and Adjuvant Immunotherapy in Early-Stage Non-Small Cell Lung Cancer. Lung Cancer 2021, 12, 51-60. [CrossRef] [PubMed] 
13. Uprety, D.; Mandrekar, S.J.; Wigle, D.; Roden, A.C.; Adjei, A.A. Neoadjuvant Immunotherapy for NSCLC: Current Concepts and Future Approaches. J. Thorac. Oncol. 2020, 15, 1281-1297. [CrossRef] [PubMed]

14. Wu, Y.L.; Tsuboi, M.; He, J.; John, T.; Grohe, C.; Majem, M.; Goldman, J.W.; Laktionov, K.; Kim, S.W.; Kato, T.; et al. Osimertinib in Resected EGFR-Mutated Non-Small-Cell Lung Cancer. N. Engl. J. Med. 2020, 383, 1711-1723. [CrossRef]

15. Hofman, P. PD-L1 immunohistochemistry for non-small cell lung carcinoma: Which strategy should be adopted? Expert. Rev. Mol. Diagn. 2017, 17, 1097-1108. [CrossRef]

16. Hofman, P.; Barlesi, F. Companion diagnostic tests for treatment of lung cancer patients: What are the current and future challenges? Expert Rev. Mol. Diagn. 2019, 19, 429-438. [CrossRef]

17. Xu, Y.; Wan, B.; Chen, X.; Zhan, P.; Zhao, Y.; Zhang, T.; Liu, H.; Afzal, M.Z.; Dermime, S.; Hochwald, S.N.; et al. Transl. Lung Cancer Res. The association of PD-L1 expression with the efficacy of anti-PD-1/PD-L1 immunotherapy and survival of non-small cell lung cancer patients: A meta-analysis of randomized controlled trials. Transl. Lung Cancer Res. 2019, 8, 413-428. [CrossRef]

18. Lin, C.; Hu, F.; Chu, H.; Ren, P.; Ma, S.; Wang, J.; Bai, J.; Han, X.; Ma, S. The role of EGFR-TKIs as adjuvant therapy in EGFR mutation-positive early-stage NSCLC: A meta-analysis. Thorac. Cancer 2021, 12, 1084-1095. [CrossRef]

19. Mitsudomi, T.; Soh, J. Adjuvant therapy of operable nonsmall cell lung cancer: An update. Curr. Opin. Oncol. 2021, 33, 47-54. [CrossRef]

20. Ortega-Franco, A.; Calvo, V.; Franco, F.; Provencio, M.; Califano, R. Integrating immune checkpoint inhibitors and targeted therapies in the treatment of early stage non-small cell lung cancer: A narrative review. Transl. Lung Cancer Res. 2020, 9, 2656-2673. [CrossRef]

21. Zhong, W.Z.; Wang, Q.; Mao, W.M.; Xu, S.T.; Wu, L.; Wei, Y.C.; Liu, Y.Y.; Chen, C.; Cheng, Y.; Yin, R.; et al. Gefitinib Versus Vinorelbine Plus Cisplatin as Adjuvant Treatment for Stage II-IIIA (N1-N2) EGFR-Mutant NSCLC: Final Overall Survival Analysis of CTONG1104 Phase III Trial. J. Clin. Oncol. 2021, 39, 713-722. [CrossRef] [PubMed]

22. Marquez-Medina, D.; Popat, S. Eventual role of EGFR-tyrosine kinase inhibitors in early-stage non-small-cell lung cancer. Future Oncol. 2016, 12, 815-825. [CrossRef]

23. Tsuboi, M.; Weder, W.; Escriu, C.; Blakely, C.; He, J.; Dacic, S.; Yatabe, Y.; Zeng, L.; Walding, A.; Chaft, J.E. Neoadjuvant osimertinib with/without chemotherapy versus chemotherapy alone for EGFR-mutated resectable non-small-cell lung cancer: NeoADAURA Future Oncol. 2021. [CrossRef]

24. FDA Approves Osimertinib for Adjuvant Treatment of Early-Stage EGFR-Mutated NSCLC. 16 February 2021. Available online: https:/ / www.ajmc.com/view/fda-approves-tagrisso-for-adjuvant-treatment-of-early-stage-egfr-mutated-nsclc (accessed on 2 August 2021).

25. AstraZeneca's Tagrisso Recommended by EMA Committee in Adjuvant NSCLC. 26 April 2021. Available online: https: //www.precisiononcologynews.com/cancer/astrazenecas-tagrisso-recommended-ema-committee-adjuvant-nsclc\# (accessed on 2 August 2021).

26. Chaft, J.E.; Dagogo-Jack, I.; Santini, F.C.; Eng, J.; Yeap, B.Y.; Izar, B.; Chin, E.; Jones, D.R.; Kris, M.G.; Shaw, A.T.; et al. Clinical outcomes of patients with resected, early-stage ALK-positive lung cancer. Lung Cancer 2018, 122, 67-71. [CrossRef]

27. Cheema, P.K.; Gomes, M.; Banerji, S.; Joubert, P.; Leighl, N.B.; Melosky, B.; Sheffield, B.S.; Stockley, T.; Ionescu, D.N. Consensus recommendations for optimizing biomarker testing to identify and treat advanced EGFR-mutated non-small-cell lung cancer. Curr. Oncol. 2020, 27, 321-329. [CrossRef] [PubMed]

28. Cao, C.; Guo, A.; Chen, C.; Chakos, A.; Bott, M.; Yang, C.J.; Zielinski, R.; Melfi, F. Systematic Review of Neoadjuvant Immunotherapy for Patients With Non-Small Cell Lung Cancer. Semin. Thorac. Cardiovasc. Surg. 2021. [CrossRef]

29. Compton, C.C.; Robb, J.A.; Anderson, M.W.; Berry, A.B.; Birdsong, G.G.; Bloom, K.J.; Branton, P.A.; Crothers, J.W.; CushmanVokoun, A.M.; Hicks, D.G.; et al. Preanalytics and Precision Pathology: Pathology Practices to Ensure Molecular Integrity of Cancer Patient Biospecimens for Precision Medicine. Arch. Pathol. Lab. Med. 2019, 143, 1346-1363. [CrossRef]

30. Ilie, M.; Hofman, P. Pitfalls in lung cancer molecular pathology: How to limit them in routine practice? Curr. Med. Chem. 2012, 19, 2638-2651. [CrossRef]

31. Kim, L.; Tsao, M.S. Tumour tissue sampling for lung cancer management in the era of personalised therapy: What is good enough for molecular testing? Eur. Respir. J. 2014, 44, 1011-1022. [CrossRef]

32. Hofman, P. The challenges of evaluating predictive biomarkers using small biopsy tissue samples and liquid biopsies from non-small cell lung cancer patients. J. Thorac. Dis. 2019, 11 (Suppl. S1), S57-S64. [CrossRef]

33. He, D.; Wang, D.; Lu, P.; Yang, N.; Xue, Z.; Zhu, X.; Zhang, P.; Fan, G. Single-cell RNA sequencing reveals heterogeneous tumor and immune cell populations in early-stage lung adenocarcinomas harboring EGFR mutations. Oncogene 2021, 40, 355-368. [CrossRef]

34. Passaro, A.; Malapelle, U.; Del Re, M.; Attili, I.; Russo, A.; Guerini-Rocco, E.; Fumagalli, C.; Pisapia, P.; Pepe, F.; De Luca, C.; et al. Understanding EGFR heterogeneity in lung cancer. ESMO Open 2020, 5, e000919. [CrossRef]

35. Sakurada, A.; Lara-Guerra, H.; Liu, N.; Shepherd, F.A.; Tsao, M.S. Tissue heterogeneity of EGFR mutation in lung adenocarcinoma. J. Thorac. Oncol. 2008, 3, 527-529. [CrossRef]

36. Yatabe, Y.; Matsuo, K.; Mitsudomi, T. Heterogeneous distribution of EGFR mutations is extremely rare in lung adenocarcinoma. J. Clin. Oncol. 2011, 29, 2972-2977. [CrossRef] [PubMed] 
37. Mohar, B.; Smojver Ježek, S.; Rajković Molek, K.; Štemberger, C.; Kurpis, M.; Kupanovac, Ž.; Samaržija, M.; Jonjić, N.; Grahovac, B. Detection of an EGFR mutation in cytological specimens of lung adenocarcinoma. Cytopathology 2016, 27, 444-451. [CrossRef] [PubMed]

38. Vigliar, E.; Malapelle, U.; Bellevicine, C.; de Luca, C.; Troncone, G. Outsourcing cytological samples to a referral laboratory for EGFR testing in non-small cell lung cancer: Does theory meet practice? Cytopathology 2015, 26, 312-317. [CrossRef]

39. Aggarwal, C.; Rolfo, C.D.; Oxnard, G.R.; Gray, J.E.; Sholl, L.M.; Gandara, D.R. Strategies for the successful implementation of plasma-based NSCLC genotyping in clinical practice. Nat. Rev. Clin. Oncol. 2021, 8, 56-62. [CrossRef] [PubMed]

40. Hofman, P. Liquid Biopsy and Therapeutic Targets: Present and Future Issues in Thoracic Oncology. Cancers 2017, 9, 154. [CrossRef] [PubMed]

41. Hofman, V.; Hofman, P. Resistances to EGFR tyrosine kinase inhibitors in lung cancer-how to routinely track them in a molecular pathology laboratory? J. Thorac. Dis. 2019, 11 (Suppl. S1), S65-S70. [CrossRef] [PubMed]

42. Hofman, P. Next-Generation Sequencing with Liquid Biopsies from Treatment-Naïve Non-Small Cell Lung Carcinoma Patients. Cancers 2021, 13, 2049. [CrossRef] [PubMed]

43. Lam, V.K.; Zhang, J.; Wu, C.C.; Tran, H.T.; Li, L.; Diao, L.; Wang, J.; Rinsurongkawong, W.; Raymond, V.M.; Lanman, R.B.; et al. Genotype-Specific Differences in Circulating Tumor DNA Levels in Advanced NSCLC. J. Thorac. Oncol. 2021, 16, 601-609. [CrossRef]

44. Pérez-Barrios, C.; Sánchez-Herrero, E.; Garcia-Simón, N.; Barquín, M.; Clemente, M.B.; Provencio, M.; Romero, A. ctDNA from body fluids is an adequate source for EGFR biomarker testing in advanced lung adenocarcinoma. Clin. Chem. Lab. Med. 2021, 59, 1221-1229. [CrossRef] [PubMed]

45. Shi, L.; Tang, J.; Tao, H.; Guo, L.; Wu, W.; Wu, H.; Liu, Z.; Tong, L.; Wu, W.; Li, H.; et al. Detection of EGFR Mutations in Cerebrospinal Fluid of EGFR-Mutant Lung Adenocarcinoma with Brain Metastases. Front. Oncol. 2021, 11, 622142. [CrossRef] [PubMed]

46. Zhang, P.; Wu, X.; Tang, M.; Nie, X.; Li, L. Detection of EGFR gene mutation status from pleural effusions and other body fluid specimens in patients with lung adenocarcinoma. Thorac. Cancer 2019, 10, 2218-2224. [CrossRef] [PubMed]

47. Bettegowda, C.; Sausen, M.; Leary, R.J.; Kinde, I.; Wang, Y.; Agrawal, N.; Bartlett, B.R.; Wang, H.; Luber, B.; Alani, R.M.; et al. Detection of circulating tumor DNA in early- and late-stage human malignancies. Sci. Transl. Med. 2014, 6, 224ra24. [CrossRef]

48. Wan, L.; Liu, Q.; Liang, D.; Guo, Y.; Liu, G.; Ren, J.; He, Y.; Shan, B. Circulating Tumor Cell and Metabolites as Novel Biomarkers for Early-Stage Lung Cancer Diagnosis. Front. Oncol. 2021, 31, 630672. [CrossRef]

49. Gerber, T.; Taschner-Mandl, S.; Saloberger-Sindhöringer, L.; Popitsch, N.; Heitzer, E.; Witt, V.; Geyeregger, R.; Hutter, C.; Schwentner, R.; Ambros, I.M.; et al. Assessment of Pre-Analytical Sample Handling Conditions for Comprehensive Liquid Biopsy Analysis. J. Mol. Diagn. 2020, 22, 1070-1086. [CrossRef]

50. Krug, A.K.; Enderle, D.; Karlovich, C.; Priewasser, T.; Bentink, S.; Spiel, A.; Brinkmann, K.; Emenegger, J.; Grimm, D.G.; Castellanos-Rizaldos, E.; et al. Improved EGFR mutation detection using combined exosomal RNA and circulating tumor DNA in NSCLC patient plasma. Ann. Oncol. 2018, 29, 700-706. [CrossRef] [PubMed]

51. Weber, S.; Spiegl, B.; Perakis, S.O.; Ulz, C.M.; Abuja, P.M.; Kashofer, K.; Leest, P.V.; Azpurua, M.A.; Tamminga, M.; Brudzewsky, D.; et al. Technical Evaluation of Commercial Mutation Analysis Platforms and Reference Materials for Liquid Biopsy Profiling. Cancers 2020, 12, 1588. [CrossRef] [PubMed]

52. Chaudhuri, A.A.; Chabon, J.J.; Lovejoy, A.F.; Newman, A.M.; Stehr, H.; Azad, T.D.; Khodadoust, M.S.; Esfahani, M.S.; Liu, C.L.; Zhou, L.; et al. Early Detection of Molecular Residual Disease in Localized Lung Cancer by Circulating Tumor DNA Profiling. Cancer Discov. 2017, 7, 1394-1403. [CrossRef]

53. Amiri, A.; Pourhanifeh, M.H.; Mirzaei, H.R.; Nahand, J.S.; Moghoofei, M.; Sahebnasagh, R.; Mirzaei, H.; Hamblin, M.R. Exosomes and Lung Cancer: Roles in Pathophysiology, Diagnosis and Therapeutic Applications. Curr. Med. Chem. 2021, 28, 308-328. [CrossRef] [PubMed]

54. Cui, S.; Cheng, Z.; Qin, W.; Jiang, L. Exosomes as a liquid biopsy for lung cancer. Lung Cancer 2018, 116, 46-54. [CrossRef] [PubMed]

55. Jouida, A.; McCarthy, C.; Fabre, A.; Keane, M.P. Exosomes: A new perspective in EGFR-mutated lung cancer. Cancer Metastasis Rev. 2021, 40, 589-601. [CrossRef] [PubMed]

56. Yin, L.; Liu, X.; Shao, X.; Feng, T.; Xu, J.; Wang, Q.; Hua, S. The role of exosomes in lung cancer metastasis and clinical applications: An updated review. J. Transl. Med. 2021, 19, 312. [CrossRef] [PubMed]

57. Radonic, T.; Dickhoff, C.; Mino-Kenudson, M.; Lely, R.; Paul, R.; Thunnissen, E. Gross handling of pulmonary resection specimen: Maintaining the 3-dimensional orientation. J. Thorac. Dis. 2019, 11 (Suppl. S1), S37-S44. [CrossRef]

58. Do, H.; Molania, R.; Mitchell, P.L.; Vaiskunaite, R.; Murdoch, J.D.; Dobrovic, A. Reducing Artifactual EGFR T790M Mutations in DNA from Formalin-Fixed Paraffin-Embedded Tissue by Use of Thymine-DNA Glycosylase. Clin. Chem. 2017, 63, 1506-1514. [CrossRef]

59. Cheung, A.H.; Tong, J.H.; Chung, L.Y.; Chau, S.L.; Ng, C.S.; Wan, I.Y.P.; To, K.F. EGFR mutation exists in squamous cell lung carcinoma. Pathology 2020, 52, 323-328. [CrossRef]

60. Anand, K.; Phung, T.L.; Bernicker, E.H.; Cagle, P.T.; Olsen, R.J.; Thomas, J.S. Clinical Utility of Reflex Ordered Testing for Molecular Biomarkers in Lung Adenocarcinoma. Clin. Lung Cancer 2020, 21, 437-442. [CrossRef] 
61. Cheema, P.K.; Menjak, I.B.; Winterton-Perks, Z.; Raphael, S.; Cheng, S.Y.; Verma, S.; Muinuddin, A.; Freedman, R.; Toor, N.; Perera, J.; et al. Impact of Reflex EGFR/ALK Testing on Time to Treatment of Patients with Advanced Nonsquamous Non-Small-Cell Lung Cancer. J. Oncol. Pract. 2017, 13, e130-e138. [CrossRef] [PubMed]

62. Cheema, P.K.; Raphael, S.; El-Maraghi, R.; Li, J.; McClure, R.; Zibdawi, L.; Chan, A.; Victor, J.C.; Dolley, A.; Dziarmaga, A. Rate of EGFR mutation testing for patients with nonsquamous non-small-cell lung cancer with implementation of reflex testing by pathologists. Curr. Oncol. 2017, 24, 16-22. [CrossRef]

63. Ellis, P.M.; Verma, S.; Sehdev, S.; Younus, J.; Leighl, N.B. Challenges to implementation of an epidermal growth factor receptor testing strategy for non-small-cell lung cancer in a publicly funded health care system. J. Thorac. Oncol. 2013, 8, 1136-1141. [CrossRef]

64. Lisberg, A.; Cummings, A.; Goldman, J.W.; Bornazyan, K.; Reese, N.; Wang, T.; Coluzzi, P.; Ledezma, B.; Mendenhall, M.; Hunt, J.; et al. A Phase II Study of Pembrolizumab in EGFR-Mutant, PD-L1+, Tyrosine Kinase Inhibitor Naïve Patients with Advanced NSCLC. J. Thorac. Oncol. 2018, 13, 1138-1145. [CrossRef] [PubMed]

65. Proto, C.; Ferrara, R.; Signorelli, D.; Lo Russo, G.; Galli, G.; Imbimbo, M.; Prelaj, A.; Zilembo, N.; Ganzinelli, M.; Pallavicini, L.M.; et al. Choosing wisely first line immunotherapy in non-small cell lung cancer (NSCLC): What to add and what to leave out. Cancer Treat. Rev. 2019, 75, 39-51. [CrossRef] [PubMed]

66. Heeke, S.; Hofman, P. EGFR Mutation Analysis in Non-small Cell Lung Carcinoma from Tissue Samples Using the Fully Automated Idylla ${ }^{\mathrm{TM}}$ qPCR System. Methods Mol. Biol. 2019, 2054, 147-155. [CrossRef]

67. Lassalle, S.; Hofman, V.; Heeke, S.; Benzaquen, J.; Long, E.; Poudenx, M.; Lantéri, E.; Boutros, J.; Tanga, V.; Zahaf, K.; et al. Targeted Assessment of the EGFR Status as Reflex Testing in Treatment-Naive Non-Squamous Cell Lung Carcinoma Patients: A Single Laboratory Experience (LPCE, Nice, France). Cancers 2020, 12, 955. [CrossRef]

68. Heeke, S.; Benzaquen, J.; Hofman, V.; Ilié, M.; Allegra, M.; Long-Mira, E.; Lassalle, S.; Tanga, V.; Salacroup, C.; Bonnetaud, C.; et al. Critical Assessment in Routine Clinical Practice of Liquid Biopsy for EGFR Status Testing in Non-Small-Cell Lung Cancer: A Single-Laboratory Experience (LPCE, Nice, France). Clin. Lung Cancer 2020, 21, 56-65.e8. [CrossRef]

69. Passaro, A.; Mok, T.; Peters, S.; Popat, S.; Ahn, M.J.; de Marinis, F. Recent Advances on the Role of EGFR Tyrosine Kinase Inhibitors in the Management of NSCLC With Uncommon, Non Exon 20 Insertions, EGFR Mutations. J. Thorac. Oncol. 2021, 16, 764-773. [CrossRef] [PubMed]

70. Hastings, K.; Yu, H.A.; Wei, W.; Sanchez-Vega, F.; DeVeaux, M.; Choi, J.; Rizvi, H.; Lisberg, A.; Truini, A.; Lydon, C.A.; et al. EGFR mutation subtypes and response to immune checkpoint blockade treatment in non-small-cell lung cancer. Ann. Oncol. 2019, 30, 1311-1320. [CrossRef] [PubMed]

71. Foggetti, G.; Li, C.; Cai, H.; Hellyer, J.A.; Lin, W.Y.; Ayeni, D.; Hastings, K.; Choi, J.; Wurtz, A.; Andrejka, L.; et al. Genetic Determinants of EGFR-Driven Lung Cancer Growth and Therapeutic Response In Vivo. Cancer Discov. 2021. [CrossRef]

72. Kim, I.A.; Hur, J.Y.; Kim, H.J.; Park, J.H.; Hwang, J.J.; Lee, S.A.; Lee, S.E.; Kim, W.S.; Lee, K.Y. Targeted Next-Generation Sequencing Analysis for Recurrence in Early-Stage Lung Adenocarcinoma. Ann. Surg. Oncol. 2021, 28, 3983-3993. [CrossRef]

73. Leonetti, A.; Sharma, S.; Minari, R.; Perego, P.; Giovannetti, E.; Tiseo, M. Resistance mechanisms to osimertinib in EGFR-mutated non-small cell lung cancer. Br. J. Cancer 2019, 121, 725-737. [CrossRef] [PubMed]

74. Marcoux, N.; Gettinger, S.N.; O’Kane, G.; Arbour, K.C.; Neal, J.W.; Husain, H.; Evans, T.L.; Brahmer, J.R.; Muzikansky, A.; Bonomi, P.D.; et al. EGFR-Mutant Adenocarcinomas That Transform to Small-Cell Lung Cancer and Other Neuroendocrine Carcinomas: Clinical Outcomes. J. Clin. Oncol. 2019, 37, 278-285. [CrossRef] [PubMed]

75. Skoulidis, F.; Heymach, J.V. Co-occurring genomic alterations in non-small-cell lung cancer biology and therapy. Nat. Rev. Cancer 2019, 19, 495-509. [CrossRef] [PubMed]

76. Blakely, C.M.; Watkins, T.B.K.; Wu, W.; Gini, B.; Chabon, J.J.; McCoach, C.E.; McGranahan, N.; Wilson, G.A.; Birkbak, N.J.; Olivas, V.R.; et al. Evolution and clinical impact of co-occurring genetic alterations in advanced-stage EGFR-mutant lung cancers. Nat. Genet. 2017, 49, 1693-1704. [CrossRef] [PubMed]

77. Chen, M.; Xu, Y.; Zhao, J.; Zhong, W.; Zhang, L.; Bi, Y.; Wang, M. Concurrent Driver Gene Mutations as Negative Predictive Factors in Epidermal Growth Factor Receptor-Positive Non-Small Cell Lung Cancer. EBioMedicine 2019, 42, 304-310. [CrossRef] [PubMed]

78. Jung, J.H.; Lee, H.; Zeng, S.X.; Lu, H. RBM10, a New Regulator of p53. Cells 2020, 9, 2107. [CrossRef]

79. Karachaliou, N.; Paulina Bracht, J.W.; Rosell, R. ARID1A Gene Driver Mutations in Lung Adenocarcinomas. J. Thorac. Oncol. 2018, 13, e255-e257. [CrossRef]

80. Yu, H.A.; Suzawa, K.; Jordan, E.; Zehir, A.; Ni, A.; Kim, R.; Kris, M.G.; Hellmann, M.D.; Li, B.T.; Somwar, R.; et al. Concurrent Alterations in EGFR-Mutant Lung Cancers Associated with Resistance to EGFR Kinase Inhibitors and Characterization of MTOR as a Mediator of Resistance. Clin. Cancer Res. 2018, 24, 3108-3118. [CrossRef]

81. Friedlaender, A.; Addeo, A.; Russo, A.; Gregorc, V.; Cortinovis, D.; Rolfo, C.D. Targeted Therapies in Early Stage NSCLC: Hype or Hope? Int. J. Mol. Sci. 2020, 21, 6329. [CrossRef]

82. Bruno, R.; Fontanini, G. Next Generation Sequencing for Gene Fusion Analysis in Lung Cancer: A Literature Review. Diagnostics 2020, 10, 521. [CrossRef]

83. Hofman, P.; Rouleau, E.; Sabourin, J.C.; Denis, M.; Deleuze, J.F.; Barlesi, F.; Laurent-Puig, P. Predictive molecular pathology in non-small cell lung cancer in France: The past, the present and the perspectives. Cancer Cytopathol. 2020, 128, 601-610. [CrossRef] [PubMed] 
84. Sauter, J.L.; Butnor, K.J. Clinical and Cost Implications of Universal Versus Locally Advanced-Stage and Advanced-Stage-Only Molecular Testing for Epidermal Growth Factor Receptor Mutations and Anaplastic Lymphoma Kinase Rearrangements in NonSmall Cell Lung Carcinoma: A Tertiary Academic Institution Experience. Arch. Pathol. Lab. Med. 2016, 140, 358-361. [CrossRef] [PubMed]

85. Thunnissen, E.; Weynand, B.; Udovicic-Gagula, D.; Brcic, L.; Szolkowska, M.; Hofman, P.; Smojver-Ježek, S.; Anttila, S.; Calabrese, F.; Kern, I.; et al. Lung cancer biomarker testing: Perspective from Europe. Transl. Lung Cancer Res. 2020, 9, 887-897. [CrossRef] [PubMed]

86. Mehrad, M.; Roy, S.; Bittar, H.T.; Dacic, S. Next-Generation Sequencing Approach to Non-Small Cell Lung Carcinoma Yields More Actionable Alterations. Arch. Pathol. Lab. Med. 2018, 142, 353-357. [CrossRef]

87. Pennell, N.A.; Mutebi, A.; Zhou, Z.-H. Economic impact of next-generation sequencing versus single-gene testing to detect geneomic alterations in metastatic non-small cell lung cancer using a decision analytic model. JCO Precis. Oncol. 2019, 3, 1-9. [CrossRef]

88. Pruneri, G.; De Braud, F.; Sapino, A.; Aglietta, M.; Vecchione, A.; Giusti, R.; Marchiò, C.; Scarpino, S.; Baggi, A.; Bonetti, G.; et al. Next-Generation Sequencing in Clinical Practice: Is It a Cost-Saving Alternative to a Single-Gene Testing Approach? Pharmacoecon. Open 2021, 5, 285-298. [CrossRef]

89. Graham, R.P.; Treece, A.L.; Lindeman, N.I.; Vasalos, P.; Shan, M.; Jennings, L.J.; Rimm, D.L. Worldwide Frequency of Commonly Detected EGFR Mutations. Arch. Pathol. Lab. Med. 2018, 142, 163-167. [CrossRef]

90. Li, W.; Guo, H.; Li, L.; Cui, J. Comprehensive Comparison Between Adjuvant Targeted Therapy and Chemotherapy for EGFRMutant NSCLC Patients: A Cost-Effectiveness Analysis. Front. Oncol. 2021, 11, 619376. [CrossRef] [PubMed]

91. Yotsukura, M.; Nakagawa, K.; Suzuki, K.; Takamochi, K.; Ito, H.; Okami, J.; Aokage, K.; Shiono, S.; Yoshioka, H.; Aoki, T.; et al. Recent advances and future perspectives in adjuvant and neoadjuvant immunotherapies for lung cancer. Jpn. J. Clin. Oncol. 2021, 51, 28-36. [CrossRef]

92. Ilié, M.; Ngo-Mai, M.; Long-Mira, E.; Lassalle, S.; Butori, C.; Bence, C.; Hamila, M.; Hofman, V.; Hofman, P. Using 22C3 Anti-PD-L1 Antibody Concentrate on Biopsy and Cytology Samples from Non-small Cell Lung Cancer Patients. J. Vis. Exp. 2018, $139,58082$. [CrossRef] [PubMed]

93. Ilie, M.; Juco, J.; Huang, L.; Hofman, V.; Khambata-Ford, S.; Hofman, P. Use of the 22C3 anti-programmed death-ligand 1 antibody to determine programmed death-ligand 1 expression in cytology samples obtained from non-small cell lung cancer patients. Cancer Cytopathol. 2018, 126, 264-274. [CrossRef] [PubMed]

94. Tejerina, E.; Garca Tobar, L.; Echeveste, J.I.; de Andrea, C.E.; Vigliar, E.; Lozano, M.D. PD-L1 in Cytological Samples: A Review and a Practical Approach. Front. Med. 2021, 8, 668612. [CrossRef]

95. Qiao, M.; Jiang, T.; Liu, X.; Mao, S.; Zhou, F.; Li, X.; Zhao, C.; Chen, X.; Su, C.; Ren, S.; et al. Immune Checkpoint Inhibitors in EGFR-Mutated NSCLC: Dusk or Dawn? J. Thorac. Oncol. 2021, 16, 1267-1288. [CrossRef] [PubMed]

96. Kneuertz, P.J.; Carbone, D.P.; D’Souza, D.M.; Shilo, K.; Abdel-Rasoul, M.; Zhao, W.; Williams, T.M.; Jones, D.; Merritt, R.E. Prognostic value and therapeutic implications of expanded molecular testing for resected early stage lung adenocarcinoma. Lung Cancer 2020, 143, 60-66. [CrossRef]

97. Ilie, M.; Long-Mira, E.; Bence, C.; Butori, C.; Lassalle, S.; Bouhlel, L.; Fazzalari, L.; Zahaf, K.; Lalvée, S.; Washetine, K.; et al. Comparative study of the PD-L1 status between surgically resected specimens and matched biopsies of NSCLC patients reveal major discordances: A potential issue for anti-PD-L1 therapeutic strategies. Ann. Oncol. 2016, 27, 147-153. [CrossRef] [PubMed]

98. Mansfield, A.S.; Dong, H. Implications of Programmed Cell Death 1 Ligand 1 Heterogeneity in the Selection of Patients With Non-Small Cell Lung Cancer to Receive Immunotherapy. Clin. Pharmacol. Ther. 2016, 100, 220-222. [CrossRef] [PubMed]

99. Dong, Z.Y.; Zhang, J.T.; Liu, S.Y.; Su, J.; Zhang, C.; Xie, Z.; Zhou, Q.; Tu, H.Y.; Xu, C.R.; Yan, L.X.; et al. EGFR mutation correlates with uninflamed phenotype and weak immunogenicity, causing impaired response to PD-1 blockade in non-small cell lung cancer. Oncoimmunology 2017, 6, e1356145. [CrossRef] [PubMed]

100. To, K.K.W.; Fong, W.; Cho, W.C.S. Immunotherapy in Treating EGFR-Mutant Lung Cancer: Current Challenges and New Strategies. Front. Oncol. 2021, 11, 635007. [CrossRef]

101. Offin, M.; Rizvi, H.; Tenet, M.; Ni, A.; Sanchez-Vega, F.; Li, B.T.; Drilon, A.; Kris, M.G.; Rudin, C.M.; Schultz, N. Tumor Mutation Burden and Efficacy of EGFR-Tyrosine Kinase Inhibitors in Patients with EGFR-Mutant Lung Cancers. Clin. Cancer Res. 2019, 25, 1063-1069. [CrossRef]

102. Smeltzer, M.P.; Wynes, M.W.; Lantuejoul, S.; Soo, R.; Ramalingam, S.S.; Varella-Garcia, M.; Meadows Taylor, M.; Richeimer, K.; Wood, K.; Howell, K.E.; et al. The International Association for the Study of Lung Cancer Global Survey on Molecular Testing in Lung Cancer. J. Thorac. Oncol. 2020, 15, 1434-1448. [CrossRef]

103. Mehta, A.; Vasudevan, S. Rare epidermal growth factor receptor gene alterations in non-small cell lung cancer patients, tyrosine kinase inhibitor response and outcome analysis. Cancer Treat. Res. Commun. 2021, 28, 100398. [CrossRef]

104. Volckmar, A.L.; Christopoulos, P.; Kirchner, M.; Allgäuer, M.; Neumann, O.; Budczies, J.; Rempel, E.; Horak, P.; Glade, J.; Goldschmid, H.; et al. Targeting rare and non-canonical driver variants in NSCLC-An uncharted clinical field. Lung Cancer 2021, 154, 131-141. [CrossRef] [PubMed]

105. Nagasaka, M.; Zhu, V.W.; Lim, S.M.; Greco, M.; Wu, F.; Ou, S.I. Beyond Osimertinib: The Development of Third-Generation EGFR Tyrosine Kinase Inhibitors For Advanced EGFR+ NSCLC. J. Thorac. Oncol. 2021, 16, 740-763. [CrossRef] 
106. Nagasaka, M.; Uddin, M.H.; Al-Hallak, M.N.; Rahman, S.; Balasubramanian, S.; Sukari, A.; Azmi, A.S. Liquid biopsy for therapy monitoring in early-stage non-small cell lung cancer. Mol. Cancer 2021, 20, 82. [CrossRef]

107. Peng, M.; Huang, Q.; Yin, W.; Tan, S.; Chen, C.; Liu, W.; Tang, J.; Wang, X.; Zhang, B.; Zou, M.; et al. Circulating Tumor DNA as a Prognostic Biomarker in Localized Non-small Cell Lung Cancer. Front. Oncol. 2020, 10, 561598. [CrossRef] [PubMed]

108. Suda, K.; Mitsudomi, T.; Shintani, Y.; Okami, J.; Ito, H.; Ohtsuka, T.; Toyooka, S.; Mori, T.; Watanabe, S.I.; Asamura, H.; et al. Clinical Impacts of EGFR Mutation Status: Analysis of 5780 Surgically Resected Lung Cancer Cases. Ann. Thorac. Surg. 2021, 111, 269-276. [CrossRef]

109. Pei, G.; Li, M.; Min, X.; Liu, Q.; Li, D.; Yang, Y.; Wang, S.; Wang, X.; Wang, H.; Cheng, H.; et al. Molecular Identification and Genetic Characterization of Early-Stage Multiple Primary Lung Cancer by Large-Panel Next-Generation Sequencing Analysis. Front. Oncol. 2021, 11, 653988. [CrossRef]

110. Fligor, S.C.; Tsikis, S.T.; Wang, S.; Ore, A.S.; Allar, B.G.; Whitlock, A.E.; Calvillo-Ortiz, R.; Arndt, K.; Callery, M.P.; Gangadharan, S.P. Time to surgery in thoracic cancers and prioritization during COVID-19: A systematic review. J. Thorac. Dis. 2020, 12, 6640-6654. [CrossRef] [PubMed]

111. Hofman, P.; Ilié, M.; Chamorey, E.; Brest, P.; Schiappa, R.; Nakache, V.; Antoine, M.; Barberis, M.; Begueret, H.; Bibeau, F.; et al. Clinical and molecular practice of European thoracic pathology laboratories during the COVID-19 pandemic. The past and the near future. ESMO Open. 2021, 6, 100024. [CrossRef] [PubMed]

112. Johnson, B.A.; Waddimba, A.C.; Ogola, G.O.; Fleshman, J.W., Jr.; Preskitt, J.T. A systematic review and meta-analysis of surgery delays and survival in breast, lung and colon cancers: Implication for surgical triage during the COVID-19 pandemic. Am. J. Surg. 2021, 222, 311-318. [CrossRef] [PubMed]

113. Malapelle, U.; Pisapia, P.; Iaccarino, A.; Barberis, M.; Bellevicine, C.; Brunnström, H.; de Biase, D.; De Maglio, G.; Ericson Lindquist, K.; Fassan, M.; et al. Predictive molecular pathology in the time of coronavirus disease (COVID-19) in Europe. J. Clin. Pathol. 2020, 74, 391-395. [CrossRef] [PubMed]

114. Patton, S.; Normanno, N.; Blackhall, F.; Murray, S.; Kerr, K.M.; Dietel, M.; Filipits, M.; Benlloch, S.; Popat, S.; Stahel, R.; et al. Assessing standardization of molecular testing for non-small-cell lung cancer: Results of a worldwide external quality assessment (EQA) scheme for EGFR mutation testing. Br. J. Cancer 2014, 111, 413-420. [CrossRef] [PubMed]

115. Bank, P.C.D.; Jacobs, L.H.J.; van den Berg, S.A.A.; van Deutekom, H.W.M.; Hamann, D.; Molenkamp, R.; Ruivenkamp, C.A.L.; Swen, J.J.; Tops, B.B.J.; Wamelink, M.M.C.; et al. The end of the laboratory developed test as we know it? Recommendations from a national multidisciplinary taskforce of laboratory specialists on the interpretation of the IVDR and its complications. Clin. Chem. Lab. Med. 2020, 59, 491-497. [CrossRef] [PubMed]

116. Barberis, M. In vitro diagnostic medical device regulation (IVDR): The end of laboratory developed tests (LDT)? Pathologica 2021, 113, 68-69. [CrossRef] [PubMed]

117. Vogeser, M.; Brüggemann, M. Complex analytical procedures in diagnostic laboratories and the IVDR. Clin. Chem. Lab. Med. 2020, 59, 457-458. [CrossRef]

118. Han, J.; Yu, R.; Duan, J.; Li, J.; Zhao, W.; Feng, G.; Bai, H.; Wang, Y.; Zhang, X.; Wan, R.; et al. Weighting tumor-specific TCR repertoires as a classifier to stratify the immunotherapy delivery in non-small cell lung cancers. Sci. Adv. 2021, 7, eabd6971. [CrossRef]

119. Hofman, P.; Heeke, S.; Alix-Panabières, C.; Pantel, K. Liquid biopsy in the era of immuno-oncology: Is it ready for prime-time use for cancer patients? Ann. Oncol. 2019, 30, 1448-1459. [CrossRef]

120. Qiu, Y.; Liu, L.; Yang, H.; Chen, H.; Deng, Q.; Xiao, D.; Lin, Y.; Zhu, C.; Li, W.; Shao, D.; et al. Integrating Histologic and Genomic Characteristics to Predict Tumor Mutation Burden of Early-Stage Non-Small-Cell Lung Cancer. Front. Oncol. 2021, 10, 608989. [CrossRef]

121. Yang, H.; Wang, Y.; Jia, Z.; Wang, Y.; Yang, X.; Wu, P.; Song, Y.; Xu, H.; Gu, D.; Chen, R.; et al. Characteristics of T-Cell Receptor Repertoire and Correlation with EGFR Mutations in All Stages of Lung Cancer. Front. Oncol. 2021, 11, 537735. [CrossRef]

122. Yu, H.; Chen, Z.; Ballman, K.V.; Watson, M.A.; Govindan, R.; Lanc, I.; Beer, D.G.; Bueno, R.; Chirieac, L.R.; Chui, M.H.; et al. Correlation of PD-L1 Expression with Tumor Mutation Burden and Gene Signatures for Prognosis in Early-Stage Squamous Cell Lung Carcinoma. J. Thorac. Oncol. 2019, 14, 25-36. [CrossRef] [PubMed]

123. Stenzinger, A.; Alber, M.; Allgäuer, M.; Jurmeister, P.; Bockmayr, M.; Budczies, J.; Lennerz, J.; Eschrich, J.; Kazdal, D.; Schirmacher, P.; et al. Artificial intelligence and pathology: From principles to practice and future applications in histomorphology and molecular profiling. Semin. Cancer Biol. 2021. [CrossRef] 